\title{
Dalit Movement in India: In the light of four Dalit literatures
}

\author{
Ruman Sutradhar ${ }^{1}$ \\ (Research Scholar, Department of Political Science, Assam University)
}

\begin{abstract}
History testifies the presence of cleavages in every society, characterized by atrocities, discrimination, exploitation and subordination that raised peoples demand for justice and equality. It is this idea of equality that forced people to protest in the form of movements. The Dalit Movement also began as a protest movement in India. The Dalits, also called as Atisudra, Panchama or Outcasts, at present constitute one of the most depressed and marginalized sections of Indian society. Socio-cultural exclusion, economic deprivation and political exploitation of centuries made them to break out of such kinds of age-old prejudices. Hence, they began to protest with the help of literatures, or forming organization like the Dalit Panthers, which came to be recognized as the Dalit Movement. This paper is an attempt to bring forth the various aspects of Dalit's lives that led to the movement, in the radiance of four Dalit literatures.
\end{abstract}

Keywords: Cleavages, Dalits, Depressed, Equality, Exploitation, Protest, Marginalization, Movement.

\section{Introduction}

History testifies the presence of social cleavages in Indian society, in terms of caste, class, gender and the like. Such cleavages has changed the entire social fabric of Indian society, whereby the exploited section, be it the Dalits, adivasis or women, have been systematically pushed to the periphery by the traditional Brahmanical structure of oppression. Dalits are the people who are economically, socially, politically exploited from centuries. Unable to live in the society of human beings, they have been living outside the village depending on lower level of occupation, and lived as "untouchable". This exploitation is due to the discrimination followed by age old caste hierarchical tradition in the Hindu society. This hierarchy has been the cause for oppression of Dalits in each and every sphere of society since centuries. It has subjected them to a life of poverty and humiliation. The Dalits(ex-untouchables), who have been brutally exploited by the so-called upper castes, lag outside the Varnasrama theory and were referred to as outcasts in pre-independent India. India attained independence, but the Dalits were not allowed to live a life with dignity and equality. It is this idea of 'equality, which sparked the beginning of the Dalit Movement in India, as a protest to the age-old atrocities committed against them. Dalit movement is a struggle that tries to counter attack the socio - cultural hegemony of the upper castes. It is a movement of the masses that craves for justice through the speeches, literary works, dramas, songs, cultural organisations and all the other possible measurers. So it can be called as a movement which has been led by Dalits to seek equality with all other castes of the Hindu society. The main objective of the Dalit Movement was to establish a society in India based on social equality. The constitutional identity, however, fails to capture the true picture. The real picture is something different which will be reflected in this paper, in the light of the four books including Debrahmanising History, Poisoned Bread, The Prisons We Broke and Dalit Visions.

\subsection{Different Connotations of the Word 'Dalit'}

Dalits, the group of people who constitute the last category of castes in the Varnasrama Theory .This is the traditional definition of the term Dalit as is given by different scholars. According to the Indian Constitution the Dalits are the people coming under the category 'Scheduled castes'. With slight changes ,however ,the term 'Dalit' would mean not Only one category of caste, it means the human who is exploited economically, socially, politically and from all the spheres of life, by the traditions of the country. By tradition would mean the 'Brahmanical Indian tradition' prevailing in the country for centuries .A Dalit does not believe in God, religion as propagated by the Hindu scriptures and religious texts, as because it is these tradition only that have made them slaves. A Dalit is the person who has the realization of the sorrows and struggles of those in the lowest stratum of the society. The Dalits, called by different names like Dasyu, Dasa, Atisudra, Panchama, Tirukulattar, Adikarnataka, Adi Dravida, are actually the "Depressed Classes" of Indian society. Dalit is one who believes in equality, who practices equality and who combats inequality. A Dalit is the believer of Humanism - the ultimate ideology of human beings. The real symbol of present Dalit is 'Change and Revolution'. Therefore, any individual from any caste category (including the Brahmin), will be considered a Dalit given the fact that the person is depressed and exploited, aspire to attain equality through change and revolution, being the firm believer of the ideology of 'Humanism'. 


\section{Brahmanism as the Root Cause of Dalit Movement: A Historical Critique}

The Dalits and women in India are, at present, categorized under the marginalized sections of the society. All these castes (Pariahs, Chamars, Mahars, Bhangis and so on) share a common condition of exploitation and oppression by the so called upper castes of the Indian society .If we trace back to the historical periods, it will be found that the root cause is the formation of the 'Caste System' which actually led to the oppression of the other categories of oppressed classes of India- the women. It was with the Aryans who entered the country from Middle East and settled in the fertile land of the Ganges after a fight with the indigenous people of the civilization. The people, well versed in the techniques as shown in historical aspects, were defeated by the Aryans. The Minority Aryans defeated the majority Dalits by the use of their tactics of Divide and Rule, as assumed by Braj Ranjan Mani because without doing so they won't be able to defeat the majority. The Brahmins had retain this tactic even today .Later in the vedic period, the formation of the Rig Veda laid the foundation of the oppression of the people in their own land, with the Purusha shukta in its tenth book. It was later in the 5th century that people of Shudra Varna were transformed to untouchable. And this led to beginning of the Brahmin domination accompanied by Dalit exploitation. A Brahman is a great God, whether he is learned or imbecile and the Brahmans should be respected in any way, even if they indulge in a crime ${ }^{1}$. These are the Religious texts of the Hindus, which strives for an unequal society, a society where a certain group of people are given the status of God, in total contrast with the other group who are considered even worse than animals. God who is considered as the Almighty do not exist, but is considered as the Supreme power. Is it that the Arya-Brahmins, devised the institution of Varna and thereby caste, in order that they consider themselves as the 'Supreme'. By putting themselves in the supreme position, they actually wanted to attain superior status, a life of dignity, and aspired to be obeyed by everyone in the Indian society. Caste, the very creation of man and not God, is now rooted firmly in the Indian society, through the religion of majority Hinduism .Gail Omvedt in her book "Dalit Visions", equated Hinduism with Brahmanism. Hinduism is constructed in order to hide the discriminatory laws of Brahmanism under a religion to be considered as the religion of the country, and thereby obeyed without any question. The caste ideology is founded in the twin religious doctrines of Karma and Dharma. And that it was the basic duty of every individual to maintain Dharma which was to retain the social structure based on the Varnasrama Theory. Not only Manu, Kautilya, another Brahmin, also emphasized on retaining the Caste structure as the basic structure of Indian society that cannot and should not be changed .The same was asserted by Gandhi, the Father of the Nation ,to change is to create disorder ${ }^{2}$. This means that the Brahmins should stay at the top of the pyramid and the Dalits at the bottom. Even if the Dalits die under the situation, they should not be uplifted. This is Brahmanism - believer of inequality, the roots of which lie in the ancient Vedas. Formulated 3500 thousand years back, the Vedas are ruling Indian society even now, through its instrument -Hinduism. It is controlling the minds of the people, which made the minority groups -the Brahmins to be the policy makers of the country. And in order to retain their position they have devised myths .For instance, they devised the myth of 'Punarjanma' which explains the phenomena of 're-birth'.It explains that the activities of our past janma, is responsible for our present status, and the activities of present will decide our life after re-bith . This myth has two connotations-

Firstly, the Dalits should accept the exploitation done against them as the result of their own deeds of past birth. They should consider that they committed some bad deeds due to which they are facing such kind of oppression.

Secondly, even if they are exploited in this birth, they should not protest, which will provide them a good life in the next birth after re-birth. That is with the desire to get happiness in the next birth, they should cry. Because it is believed that, God will help them to come out of distress, and that the Brahmins being Gods are the only solution for their distress. If these texts are observed closely in socio -historical perspective, the aim to write these texts become clear, which is to establish and maintain Brahmanical hegemony, and exploit the non -Brahmins , basically the Dalits.

\section{Dalits -Human or Animals (In The Light Of Socio-Economic Background)}

Deprivation of resources at every sphere of social, economic and political lives, led to a state of immense oppression and degradation. The basic reasons for this degraded status of the Dalits is caste system leading to untouchability, monopoly of resources and monopoly of knowledge. Not only are Dalits extremely poor, rather half of the Dalit Population are living below the poverty line as compared to less than one-third of the rest of the population .Today, they are almost totally dependent upon the dominant castes for their livelihoods as agricultural or urban labour. During the Buddha period, the Aryans tried to monopolize resources. For economic control and social status they monopolized resources. Universally, control over land as a resource for production and certain other resources were regarded as making for high status. Thus began the real

\footnotetext{
${ }^{1}$ B R Mani, Debrahmanising History (Manohar Publishers: New Delhi,2005)

${ }^{2}$ B R Mani, op.cit.
} 
exploitation. With their control over land, the Dalits lost their livelihood and began to be degenerated to the status of animals. The practice of untouchability and the lack of knowledge made them to believe all those superstitious and unreasonable myths formed by the cunning Brahmins. They were deprived of the three basic needs of society -food, shelter and clothing. Deprived of food, they filled their stomach with stale pieces of food and dead animals as if they were not humans. In the story "Cull" in Dangle's Poisoned Bread, written by Amitabh ,it was explained how the Dalits struggled even to have pieces of bone of a dead beaf. Words will be less to explain the situation of the Dalits in that particular story. They covered their body with pieces of rags stitched together. The so called high castes- the Brahmins gave food to the beasts but not to the Dalits. The Brahmins got polluted if the shadow of the Dalits fall on them, but their food do not get polluted when cooked by the firewood brought by the Dalit women, in which many a times the blood of their cut fingers get sticked . This is an indication of the fact that the rules made against the Dalits are basically for their own benefits.

The Dalits were believed to be unclean and therefore must not touch anybody belonging to one of the four main castes. If they do, or even if their shadow falls on a upper caste member, the person is deemed to have been polluted and must perform a series of cleansing rituals in order to rid their body of this pollution. It is as if a Dalit has an actual disease such as leprosy, such was the discrimination against them. And it is to fulfill the stomach, they had to do the dirty works, as no work was left for them in society. Even knowledge was monopolized by the Brahmins. Shudras are not entitled to education, to amass wealth, or bear arms. A Brahman can take away any possession from a Shudra since nothing at all can belong to him as his own (Mani .57). The Aryans who themselves came to the sub-continent from Middle-East pushed the inhabitants of the land to jungles, depriving them of their own land and resources. How far is it justifiable? Or, is it justifiable at all? It is thus the Vedas, which are considered as the sole source of knowledge, were kept away from the touch of the Dalits and women. This again has three connotations-

Firstly, this would deprive the Dalits from knowledge and education, by which they could keep the Dalits in the animal status only. They will not know the meaning of equality and dignity.

Secondly, the Brahmins were scared that if the Vedas were read by the oppressed sections, the real picture of Brahmanism will come in front of them, as because this will lead them to lose their status. The Dalits, being educated will judge the Vedas based on reason.

Thirdly, this will make them not to claim their right as education can help them to raise economic status. If Dalits become literate, they can move beyond unskilled labour, earn more money, and so gain greater respect.

The other is making life-style changes which get rid of those practices considered especially "low" or "polluting" and substituting those of the "higher" castes instead. Lack of food, shelter, clothing made them to lead a miserable life. A life, entangled by unreasonable superstitious beliefs on one side , and lack of education on the other by economic and social exploitation degenerated their life into that of animals. Just like the beasts , the Dalits were made to beg for food to eat, good clothes to wear and land in the open sky to live. The Dalits were forced to work as manual works like scavenging or as bonded- labour their own land, or they would not be given food. In return of their labour of whole day, some crumbs stale bread was thrown to them. Can a group of people living under such socio- economic situation, be called human beings? Or, it should be accepted that it is Brahmanism that is responsible for giving the group of human beings called Dalits as mere animals.

\subsection{Dalit Women-Forced into Prostitution}

While Dalit women share common problems of gender discrimination with their high caste counterparts, they also suffer from problems specific to them. Dalit women are the worst affected and suffer the three forms oppression -- caste, class and gender. Today, the Dalit women have extremely low literacy and education levels, heavy dependence on wage labour, discrimination in employment and wages, heavy concentration in unskilled, low-paid and hazardous manual jobs, violence and sexual exploitation, being the victims of various forms of superstitions. The very condition of the Dalit women has its root in the Vedic period. They have to work either as maids or bonded labourers, where they have to face sexual harassment from the upper caste male , or they will be turned as prostitutes by society. Bhimrao Shirwale, in the story Livlihood has explored the real face of Brahmanisn which exists even today. The story depicts how a poor Dalit girl in order to fill her stomach was compelled to sell her body. Her beauty became the greatest hurdle of her life which made the men to look at her with lusty eyes. This is not the only instance, such things are common to all the Dalit girls. Woman is the root of any society and if women are controlled, the entire community can be controlled.

Hindu religious institution were used as an instrument to exploit the Dalit women, and thereby, making them silent. It was thus, the famous ritual of 'Devadasi' was formed, whereby the non-Brahmin women, in the name of serving god were made to serve the Brahmin priests. This service was actually physical service. In other words, the women were sexually harassed and raped. The only difference is that the women accepted such sexual harassment as a means to serve God. If God really exist and is considered to be the equal for all , then how come God for His benefit make one community to be silent after such loss of Dignity. It is said that Draupadi, who was going to be raped by Duryodhana, was dressed with a saree of infinite length by Lord 
Krishna . If it had been so, how come God Himself create rules (as was said by the Brahmins, the Vedas and Smritis being the creation of God) to undress the Dalit girls in the system of Devdasi . And this system prevails only for the lower castes. The service from the Brahmin girls was not sought by God. How discriminatory the rules were created? Actually, the rules were made in such a way that only one section of society benefit, and so was the tradition made. If the Brahmanas considered the tradition so important, why did they not just sent out their women to be Devdasis (Chakraborty. 89). Dalit women have to protect their body in each and every aspect of life. Beauty itself is a curse for them. Husbands would question her modesty and other man would try to fulfill their desires- thereby turning them as prostitutes. Everyone would use them and throw out as old clothes. If a Brahmin man has sexual relations with the Dalit women, he is well respected, contrary to the Dalit woman who is excommunicated. The Dalit women face atrocities by the men of all the four varna, the basic kind of which are sexual in nature. If the women is single and without family, then it is the best opportunity .Because in search of work they would go to the upper caste only. If appointed as home maid, they will have to work not only for the home but fulfill the sexual desires of the appointer also . If they reject, they will be thrown out. Finally, finding no way, to live they would begin to sell their body, and become the prostitutes of all the sections of society. This is how, the Dalit women are made the prostitutes of society.

\subsection{Major Causes of the Dalit Movement}

\section{Dalit movement in India}

The Dalit Movement is the result of the constant hatred being generated from centuries in their heart from the barbaric activities of the upper castes of India. Since Dalits were assigned the duties of serving the other three Varnas, that is all the non- Dalit, they were deprived of higher training of mind and were denied social-economic and political status. The division of labour led to the division of the labourers, based on inequality and exploitation. The caste system degenerated Dalit lifes into pathogenic condition where occupations changed into castes. The higher castes of the society looked down upon the Shudras. It was a general belief that the Dalits are part of the lowest of low Varnas. Thus for centuries Dalits have been positioned at the bottom of the rigid Indian caste society. People from other castes, who considered themselve to be higher, believe that Dalits are impure by birth and that their touch or sheer presence could be polluting. Hence, they are assumed to be untouchable. For centuries, Dalits were excluded from the mainstream society and were only allowed to pursue menial occupations like cleaning dry latrines, sweeping, tanning or working as landless labour for meager daily wages. They were the people who cultivated the land and worked as bonded labour, did the work of scavenging and did all types of manual works. The most inhuman practice is that of untouchability, which made the Dalits to live in extreme inhuman situations . In other words, they lived a barbaric life. Starving for food in their own land where they themselves are the owner of the land,enraged the Dalits . This has made the Dalits to rise and protest, against the inhuman practices of Brahmanism .Dalits were discriminated in every sense. They lived in the Hindu villages hence did not have advantage of geographical isolation like tribes. They were pushed to the jungles whereas, the mainland was occupied by the Brahmins. They were to serve all classes of people around and had to do all the dirty jobs. They were barred from entering into those mainland areas in every sense, they were prohibited to wear decent dress and ornaments besides being untouchable. Many of the atrocities were committed in the name of religion. Besides, the system of Devadasi they poured molten lead into the ears of a Dalit, who happened to listen to some mantra. To retain the stronghold on people, education was monopolized.

From the vedic age the Dalits began struggle against oppression and exploitation. The most striking aspect of Manus formulations is in the sphere of punishment for breaking law where the quantum of punishment for the offender increases as one goes down the caste hierarchy (Chakraborty .11) .From the classic instances of Shambuk who was killed for acquiring spiritual knowledge and Eklavya who was forced to cut off his thumb for his prowness to archery ,the Dalits were always punished. Their only fault was that they are 'Dalits', and that they did not have any right to attain knowledge. Dronacharya could not take off the art of archery from Eklavya finally punished him by taking away his finger. The Dalits were always been punished for the deeds that they didn't commit, just because it was coming in the way to the Brahmins. Whenever they constitute a threat to the Brahmanic hegemony, the Brahmins would not leave a chance to punish them .The Dalits were never placed in their rightful position, which they deserve. Today, they constitute the marginalized section of society .The reason behind this is that they were denied access to resources -material or intellectual as well as were exploited .It was thus the Dalits decided to stop the following of such unequal practices in society where one group benefits stealing from the other and began their movement due to the fact that they were denied equal status.

\subsection{Dalit Movement-The Struggle of the Submerged Communities}

The Dalits-the submerged communities of India, began their movement in India with their basic demand for equality because they struggle to combat inequality in society as having firm belief in the ideal of 'equality'. 
The inhuman and barbaric practices committed against the Dalits, led them to protest against the caste -based hierarchical system of India, that has divided Indian society on the basis of caste (based on Varna system), class (Brahmin haves and non-Brahmin have nots) and gender. The Dalit movement that gained momentum in the post independence period, have its roots in the Vedic period. It was to the Shramanic -Brahmanic confrontation and then to the Mukti Movement (term given to Bhakti Movement by G.Alosius). The Mukti movement was led by very poor Dalits who fought against the saint - poets of the time. With the introduction of western language, and with the influence of the Christian missionaries, the Dalits began to come across the ideals of equality and liberty and thus began the Dalit Movement in modern times. The frustrated Dalit minds when mixed with reason began confrontation against the atrocities of Brahmanism. Educated Dalit, gradually begin to talk about the problems of poor and about exploitation and humiliations from the upper castes without any hesitation educated Dalits tried to explain to the other illiterate brothers about the required change in the society. Dalit Movement gave rise to the birth of many writers and journalists. A new group of thinkers emerged among Dalit community. Many writers through their writing made the people to be aware of exploitation carried on them by the elite section of the society. In the 1970s, the Dalit Panther Movement began in Maharashtra. The most fundamental factor responsible for the rise of Dalit Panthars was the repression and terror under which the oppressed Dalits continued to live in the rural area. Inspired by the Black Movement, the Dalit Panthers was formed by a group of educated Mahars in order to lead the movement . The Dalit movement cannot be understood without the Dalit Literary Movement.

\subsection{Dalit Literary Movement}

At a time, when there was no means of communication to support the Dalits, pen was the only solution. The media, newspapers were all under the control of the powerful class -the Brahmins. Given that the Brahmins would never allow the Dalits voice to be expressed, as it would be a threat for their own survival, the Dalits began their own magazine and began to express their own experiences. Their pen wrote not with ink, but with blood, of their own cuts -the cuts being basically mental, with instincts of physical in them. Dalit literature, the literature produced by the Dalit consciousness, emerged initially during the Mukti movement. Later, with the formation of the Dalit Panthers, there began to flourish a series of Dalit poetry and stories depicting the miseries of the Dalits the roots of which lies in the rules and laws of Vedas and Smritis. All these literature argued that Dalit Movement fights not only against the Brahmins but all those people whoever practices exploitation, and those can be the Brahmins or even the Dalits themselves. New revolutionary songs, poems, stories, autobiographies were written by Dalit writers . All their feelings were bursting out in the form of writings. Writing is not simply writing, it is an act that reflect ones continous fight against evil. It seemed as if the entire Dalit community found the space to break out their silence of thousand years. Such effective were the writings that each of its word had the capability to draw blood. The songs were sung in every village, poem and other writings were read by the entire community. Educated Dalit and intellectuals begin to talk about the problems of poor and about exploitation and humiliations from the upper castes without any hesitation educated Dalits tried to explain to the other illiterate brothers about the required change in the society. Dalit literature, try to compare the past situation of Dalits to the present and future generation not to create hatred, but to make them aware of their pitiable condition. It is not caste literature but is associated with Dalit movement to bring about socio economic change, through a democratic social movement.

\section{Preservation of Brahmanism: A Marxist Connotation}

Despite the fact that a group of educated Dalits began movement against the exploitation of Brahmanism, it could not succeed even now. There are varied reasons for which the movement could not be successful and Brahmanism is well preserved in the social structure of India .The Arya-Brahmins , the originator of the Vedas have actually institutionalized discrimination through the institution of caste .The majority are accepting caste system because the dominant ideology is inflicted in peoples mind by the process of hegemony. Brahmanism, in order to continue discrimination has made use of Gramscian 'hegemony' through social institutions like schools, temples, to maintain their hegemonic status. The majority accepted Brahmanic Ideals as their own and thus, they are discriminated with 'consent'. The Brahmins have very systematically deprived the Dalits from their own land and resources. However, since no dominant ideology goes unchallenged, and the exercise of power involves resistance, the dominant Brahmanical ideology of caste is also being resisted by a small group, that took the shape of Dalit Movement. Thus, it were the few educated Dalits who organized the majority to begin the movement. Indian structure has become pyramidal - the top place is occupied by the 'minority Brahmins' sitting at the topmost chairs in every Department, and the bottom is occupied by the 'majority non-Brahmins' pushed to the low-grade manual works. In a Marxist connotation, the 'Brahmin superstucture' is controlling the mode of production, in order to exploit the 'Dalit base', through ideology inflicted in people's mind through 'cultural hegemony'. And the major role in this is played by the writers who are writing with the touch of a Brahmanism. The writings produced by these writers reflect the problem of 
Dalits not as written by the Dalit writers. This is because those writers were Brahmanized by the Brahmanic ideals in their mind. This is how the majority minds are controlled by the Brahmanical ideology through hegemony. To control minds, socio-religious institutions are used as the main instruments which made the people to accept these rules as their own, the gods as their own and the caste -based tradition as their own creation, when this has been very systematically shaped, preserved and protected by the Brahmins. Blank minds can be filled but when the Dalit minds are already filled by the Brahmanical ideas, it is very difficult to change . Despite this, the Brahmins have further preserved caste through the institution of marriage. The Vedas followed by Manusmriti picturizes women in such a way that women need to be controlled in order to preserve caste. Marriage should be within the caste only or it will lead to social degeneration. Thus began the practice of gender discrimination leading to the Brahmanic hegemony in Indian society. Caste and gender are linked, each shaping the other and where women are crucial in maintaining the boundaries of castes (Chakraborty . 34) .A child acquires caste by birth and thus, if the women are married within the caste, it will automatically preserve caste in the society. Casteism is well preserved by the institution of 'arranged marriage' where the father gift his virgin daughter to another man of same caste, through the ritual of 'Kanyadan'. On one side, the meagre Dalit -elites have become the puppets in the hands of the Brahmins, and on the other, the Shudras are discriminating the Ati-Shudras, both of which are Dalits. This discrimination made the majority of Brahmanised Dalits to accept the Brahmanical domination willingly.

\section{Power-Means to Attain Dignity}

The Dalits devoid of any particular work are vulnerable to all the evils of society. The situation of the Dalits was such that they lived the life of animals. And it was the lack of knowledge, that was responsible for the degeneration of the Dalits into animals. To end that state of exploitation, and live a life of dignity, the only thing required was power. Power on other side can be cut by only power. Hence, to attain power, the first thing required is knowledge. It was thus, Phule and Ambedkar gave the main emphasis on the education of the Dalits, which will not only bestow them with reason and judgement capacity, but also political power , and thereby socio - economic status and a life of dignity. They knew that the political strategy of gaining power is either an end in itself or a means to other ends . In other words, if the Dalits have power, then they do not have to go begging to the upper castes. Also they will get greater economic and educational opportunities. The upper castes enjoy social power ,regardless of their individual circumstances with respect to their control over material resources, through their linkages with the other caste fellows in the political system -in the bureaucracy, judiciary and legislature (chakraborty . 13). And so, the Dalits require power to control the economic scenario and thereby the politics of the country. Thus, they sressed on the importance of education, essential requirement to regain their status in Indian society. Phule thus added that without knowledge, intellect was lost ; without intellect, morality was lost ; without morality, dynamism was lost ; without dynamism ,money was lost ; without money Shudras were degraded (demoralized), all this misery and disaster were due to the lack of knowledge(Paik.1)! However, it was Phule, who for the first time recognized the immense importance of education .Inspired by Thomas Paine's "The rights of Man", Phule sought the way of education which can only unite the Dalits in their struggle for equality. The movement was carried forward by Ambedkar who contested with Gandhi to give the Dalits, their right to equality.Gandhis politics was unambigously centering around the defence of caste with the preservation of social order in Brahmanical pattern. Gandhi ,highly influenced by Brahmanical rules, had established himself as the supreme leader of Hindu society and therefore, he could not accept the fact that Ambedkar, a mere Dalit should rule the social scenario. He was fighting for the rights of Dalits but was not ready for inter-caste marriage as he knew only marriage can preserve caste. Gandhi who described himself as an untouchable by choice did nothing but played the game of power politics. The classic example is the Hunger Strike unto death to protest the reservation of Dalits to choose their own leaders, leading to the signing of the Poona Pact .May be, he was scared that Ambedkar will win and that the Dalits will be uplifted. He could neither change the attitude of caste Hindus nor satisfy the untouchables as the practice of untouchability and discrimination continued to operate against the Dalits. To the untouchables Hinduism based on the Vedas, Smritis, Shastras were responsible for the system of caste the nature of which is exploitative and oppressive. Inequality in Hindu society stunts the progress of individuals and in consequence stunts society. The same inequality prevents society from bringing into use powers stored in individuals . In both ways, this inequality is weakening Hindu society, which is in disarray because of the four - caste system (Dangle .268). This inequality should be replaced by equality and thus, Ambedkar asserted that the Dalits need to be educated, and unite to crush the Brahmanical power and lead the movement . In the words of Ambedkar ,Educate, Organize and agitate. Education, the major source of reason, inflicts human mind with extensive knowledge of the world, whereby, they can know the truth of aphenomena ,that is reality. It therefore, would help to know the truth of Brahmanism in Indian society , and will make them to agitate against caste based inhuman practices. Only when agitation begin, in the real sense, can the Dalit be able to attain power and win the movement against exploitation, and then only can the Dalits live a life of equal status and dignity . 


\section{Conclusion}

Dalit Movement, a social revolution aimed for social change, replacing the age old hierarchical Indian society, based on the democratic ideals of liberty, equality and social justice, has begun much earlier, became intense in the 1970s and began to deem at present. One reason behind this, as pointed out by Uma Chakraborty, is that the academicians are not paying much attention. Books on Dalit Movement are written but these books do not reflect the actual things and are written keeping in view the Brahmin elites. No one want to confront with those who have power. Besides this, the minds of the people are brahmanised through hegemony. Yet another vital issue is that the movement lack people from all the communities of Dalits. For instance, in Maharashtra, the Mahars dominated the movement. The other Dalit communities like the Mangs, Chamars were not actively involved in the Movement. As Kamble pointed out that the Mangs and Chamars had their traditional duties, whereby, they could somehow manage their food .But the Mahars did not have any traditional duty which made them toprotest. At present there came up many new issues. The Dalits who got power became the dolls in the hands of the Brahmins. Many of them tend to imitate the Brahmins changing their surnames and thus identity. They are ashamed of being called Dalits which make them to discriminate against their own kith and kins. It should be noted that Dalit Movement is against Brahmanism and not Brahmins. The Brahminism is a mental state which accepts superiority of one man over another man. It gives more respect and profit for the caste which is up in the ladder of caste system, and as it goes down the ladder, resources and respect also decreases. It's contribution for the Dalits which is lowest of all the castes is nothing but exploitation, jeering and slavery. This mental state of Brahminism not only exists in Brahmins but also in Shudras, who simply shape the ideas of Brahmanical practices without testing them with scientific temperament and reasoning. India got independence but the Dalits are humiliated even now. Untouchability is abolished but injustice practices are not. Today to wear good clothes is not forbidden, but to get good job is. In the name of reforms and social uplift, today's political and social systems are pitting one group against the other, sowing hatred and perpetuating a sense of rejection from the past. Education is the only remedy for such discrimination. Thus the Movement for social change will succeed only when all the Dalits unite together to fight for equality. However they should accept that caste that is deeply rooted in peoples mind cannot be erased. So here social change would mean to get rid of discriminatory practices and get rights, necessary for the upliftment of the backward section of society-the Dalits.

\section{References}

[1] B.R. Mani, Debrahmanising History-Dominance and Resistance in Indian society (New Delhi: Manohar Publishers,2005)

[2] U. Chakraborty, Gendering Caste: Through a Feminist Lens (:Popular Prakashan,2003)

[3] S. Paik, Daughters of the Lessar God: Dalit Women's Education in Postcolonial Pune, doctoral diss., University of Warwick, United Kingdom, PhD,2007

[4] A. Dangle, Poisoned Bread (New Delhi: Orient Blackswan, 2009)

[5] B, Kamle, The Prisons We Broke (New Delhi: Orient Blackswan, 2009)

[6] G. Omvedt, Dalit Visions: The Anti-caste Movement and the Construction of an Indian Identity (New Delhi: Orient Blackswan,2006) 